\title{
Urdimento
}

Revista de Estudos em Artes Cênicas

E-ISSN: 2358.6958

\section{não existem espaços inocentes}

Claudia Bosse

Tradução: Stephan Baumgärtel e Talita Corrêa

\section{Para citar este artigo:}

BOSSE, Claudia. não existem espaços inocentes. Trad.

Stephan Baumgartel e Talita Corrêa. Urdimento,

Florianópolis, v. 2, n. 38, ago./set. 2020.

DOI: http:/dx.doi.org/10.5965/14145731023820200043 
não existem espaços inocentes ${ }^{1}$

Claudia Bosse ${ }^{2}$

Tradução: Stephan Baumgärtel ${ }^{3}$ e Talita Corrêa ${ }^{4}$

\begin{abstract}
Resumo
O texto indaga as relações entre imaginação (social) e processos de configuração espacial. Pergunta como espaços ideológicos e espaços imaginários se entrelaçam na construção de espaços concretos, que materializam regras de convivência e separação sociais. Indaga como espaços e conhecimentos inacabados contribuem para engessar relações sociais no sentido de imobilizar a reflexão por fixá-la na falta ameaçadora que esse inacabamento formal incorpora.
\end{abstract}

Palavras-chave: Espaço social. Espaço ideológico. Percepção espacial e social.

there are no innocent spaces

\begin{abstract}
This processes reflects on the relations between social imagination and the processual configuration of space. It asks how ideological and imaginary spaces are intertwined in the construction of concrete empirical spaces that materialize the rules of social connectitivity and separation. It reflects on how unfinished spaces and knowledges contribute to fixed social relation in the sense of immobilizing the reflection by focusing it somewhat obsessively on the threatening lack that this formal unfinishedness incarnates.
\end{abstract}

Keywords: Social space. Ideological space. Social and spatial perception.

\footnotetext{
Originalmente publicado em Eke, Norbert Ott; Haß, Ulrike; Kaldrack, Irina. (orgs.) Bühne. Raumbildende Prozesse im Theater. Paderborn: Wilhelm Fink Verlag, 2014, p. 63 - 81. @ Wilhelm Fink Verlag, ein Imprint der Brill Gruppe (Koninklijke Brill NV, Leiden, Niederlande; Brill USA Inc., Boston MA, USA; Brill Asia Pte Ltd, Singapore; Brill Deutschland GmbH, Paderborn, Deutschland)

2 Diretora teatral, artista visual e coreógrafa. Diretora artística do theatercombinat vienna, que ela ajudou a fundar em 1996. Desde então, apresentou e continua apresentando seus projetos e instalações cênicos e intervenções urbanas no mundo inteiro.

${ }^{3}$ Prof. Dr. Programa de Pós-Graduação em Teatro (PPGT) do Centro de Artes, Universidade do Estado de Santa Catarina (UDESC). stephao08@yahoo.com.br

${ }^{4}$ Bolsista de Iniciação Científica (Cl) no projeto "Encenação enquanto Instalação" do prof. Dr. Stephan Arnulf Baumgärtel.
} 
todo o espaço é parte de uma estrutura territorial e geopolítica ou então todo o espaço é parte de determinado acordo ideológico ou sistema, ou objeto de uma negociação ideológica espaço é ideologia não existem espaços inocentes ${ }^{5}$

alguns pensamentos, perguntas, descrições

imaginação, síntese, fragmento

espaço é produzido através da imaginação, por meio do processo construtivo do sujeito; isso acontece em um lugar, e esse lugar é parte de um sistema de conflitos e acordos. imaginação é marcada por esquemas, experiências e lembranças individuais, biológicas, políticas, sociais e culturais. a pergunta que surge é: por meio de quais padrões são produzidas que tipo de conclusões imaginativas? como funciona a gramática das lembranças da qual depende a construção do espaço? como são formulados e acordados tais parâmetros de maneira social? quais saberes, ou afirmações, ou ameaças, são geradas como e por quem ou por que elemento? e como chegam tais suposições até mim, nesse caso, o sujeito exemplar? como adentram meus valores, lembranças e ideias, que logo são por mim ponderados? ou então, como se tornam determináveis, analisáveis, compreensíveis na combinatória de suas influências mútuas os saberes, as suposições e as lembranças, se uma parte essencial dos processos de configuração do espaço é entregue a esse agente previsivelmente imprevisível, a imaginação, dentro do sujeito singular; a esse sujeito que em primeiro lugar cria o espaço em sua imaginação?

a imaginação, como processo construtivo de composição de informações, é um processo de completar algo; que junta determinadas informações para compor “algo" completo. a imaginação é parte do processo de configurar o espaço. ela absorve as informações materiais num determinado lugar e organiza

${ }^{5}$ Mantivemos a escrita do original de usar apenas palavras em minúscula, inclusive no início da frase, sendo que na escrita normalizada de alemão, todos os substantivos ou formas substantivadas são escritas em maiúscula. Respeitamos também algumas particularidades de diagramação textual dos parágrafos presentes no original. [N.T.] 
conhecimento ideológico, religioso, políticos, e científico, de forma a dar a essa composição um sentido; a produzir um espaço.

um pensamento foi despertado pela questão, por que

alguma coisa que ainda não está completamente construída, como o muro de segurança em israel, acaba de gerar exatamente uma cerca de segurança em forma de pensamentos, e desse modo fabrica a ideia do objeto (apenas aludido em termos materiais) na consciência de uma comunidade (por exemplo a dos cidadãos de israel) de maneira muito mais concreta do que se existisse o objeto como construção tátil acabada; como manifestação de uma ideia fechada e simultaneamente problemática. a manifestação arquitetônica poderia, então, virar passado, ao invés de incessantemente se tornar presente na imaginação ativa dos participantes dessa comunidade. por que isso é assim?

por que o que é apenas parcialmente materializado e, como ideia é ameaçado e não acabado, se torna mais existente e presente na consciência de muitos?

a minha resposta é que dessa maneira o conflito, que desencadeou essa construção como fronteira simultaneamente ideológica e tátil, é constantemente criado e renovado, exatamente por causa da ausência de uma completude funcional, lógica e tátil dessa estrutura. isso significa que a imaginação de cada um é sempre parte da confecção desta ideia. e sua consequência é que irrompe sempre de novo a fissura que a materialização arquitetônica evoca; a possibilidade de outro desfecho se abre constantemente, exatamente por causa do desfecho quase em aberto desse projeto inacabado. dessa maneira, o conflito que foi a causa da construção do muro de segurança bem como a profunda desconfiança e os questionamentos atrelados a ele, são constantemente reativados na imaginação do indivíduo - a imaginação do indivíduo que é organizada a partir de diferentes conviç̧ões, observações, emoções de cada pessoa que não apenas reproduz, mas antes produz esse muro de segurança. a imaginação do indivíduo, o imaginário coletivo, se tornam o verdadeiro campo de batalha desse conflito, já que o conflito que supostamente fez essa construção necessária ali é evocado e reproduzido sempre de novo. ele se manifesta na consciência por meio dessa repetição necessária; por meio dessa divisão do espaço incerta, aberta e simultaneamente insinuada; por meio dessa sugestiva territorialização do espaço 
religioso-político, de processos de in-/exclusão, de separação e de uma geografia do medo.

as coreografias da imaginação, o desencadeamento de movimentos na imaginação de nações, agrupamentos, comunidades, que também são ocasionadas e determinadas por mecanismos políticos, são um lugar essencial para a negociação de processos de configuração espacial. esses processos pressupõem uma determinada ética acerca de relações avaliativas, das fronteiras, da in- ou exclusão, presentificando, assim, as margens das concepções visuais, perceptuais e/ou imaginárias.

as atribuições, comparações e diferenciações são partes inerentes e constituintes de cada processo de configuração espacial.

o que é a especificidade da imaginação, que complementa as informações selecionadas de maneira determinada e as negocia, num processo de síntese construtiva no qual diferentes informações são reunidas e associadas?

a imaginação é o pressuposto da síntese, ou são dois recursos paralelos e claramente diferentes?

será que a síntese é também a análise de diferentes conexões? e será que a imaginação é aquela ferramenta mais inconsciente, marcada social, cultural, politica e biograficamente que complementa determinadas informações para criar uma "imagem" das informações? será que a imaginação é a produção bem fluída de uma unidade composta por partes diferentes, ou ela é o enquadramento mental, o campo de tensões de um determinado conflito, no qual informações irreconciliáveis são reunidas?

como esses dois processos se vinculam à processos de configuração espacial?

se a imaginação é a imitação de uma representação interna6 ${ }^{6}$ de onde provém o conhecimento dos componentes dessa representação que possibilita essa imitação?

${ }^{6}$ Traduzimos como "representação interna" a palavra Vorstellung, apesar do prefixo Vor significando pré, antes, em direção à, uma vez que aqui é importante diferenciar entre um imaginar representacional e outro 
toda a representação interna é, portanto, também memória. e espaço é sempre representação, uma configuração na representação, na síntese, por meio da junção de determinadas informações que na minha representação evocam uma imagem de uma informação já existente dentro de mim, ou de várias informações.

"para reconhecer qualquer coisa no espaço, por exemplo, uma linha, eu preciso a traçar, e assim, de maneira sintética, efetuar determinada relação entre as variáveis dadas, de forma que [...] por meio disso seja conhecido um objeto (um espaço específico)." (kant, crítica da razão pura, parágrafos b 137-138)

o processo de análise termina no reconhecimento sobre a essência de um fenômeno e de suas conexões internas. o processo de síntese inverte esse mecanismo e busca compor com os elementos que surgiram através da análise algo novo e completo. dialeticamente falando, a síntese eleva o singular para o nível da generalidade, o concreto para o abstrato; ela resume as variáveis em uma unidade. através disso, chega-se em conceitos mais complexos fazendo uso de conceitos basais.

um espaço com limites abertos

a negociação do espaço

como é que o inacabado compromete e vincula processos de complementação e de síntese?

o que é um lugar?

o que faz de um lugar um lugar?

como se percebe um lugar?

o que torna um lugar, um ponto geograficamente determinável, um espaço?

propositivo. Bosse usa Vorstellung no sentido de um processo interno que evoca uma vivência passada. Por isso, representação. Mas como se trata de um processo mental, optamos por "representação interna" para designar que ela é uma estrutura mental e não uma concretização material. 
com que tipo de conhecimento, de experiência cultural, social, política e individual consigo perceber a fronteira, por exemplo, entre israel e os territórios ocupados? essa fronteira é uma parte de israel e uma parte também do inexistente, ou obstinadamente existente, estado palestino (a leitura dessa distinção insinuada se transforma, dependendo se essa pessoa acredita na solução de um estado único com direitos iguais ou na de dois estados diferentes).

a imagem interna do espaço e de suas expansões líquidas, de sua representação bidimensional, como, por exemplo, em mapas, etc, determina a imagem interna de uma nação acerca de sua terra. a representação bidimensional é um esboço abstrato que traduzimos para um contexto que tem sentido e assim cria uma consciência de sua fronteira.

essa abstração reparte, secciona e determina um enquadramento para o pensar, como, por exemplo, o limite ameaçado de uma configuração ideológica; dentro e fora desse enquadramento SÃO GERADOS os espaços ideológicos daqueles que PARTICIPAM E CONSTROEM JUNTOS esse conflito espacial (por exemplo, os cidadãos dessas regiões, e os simpatizantes da esfera pública mundial com suas posições diversas). a abstração representada de um modo ou de outro é o enquadramento de uma cena ideológica que se traduz em práticas de uso do espaço, de procedimentos espaciais, mas que também se mostra visível nas maneiras como se distribui os pesos ideológicos nesse campo; uma cena que se traduz na confecção do espaço por meio da construção mental; na aceitação dessa ou aquela categoria implícita ou a sua oposição, dentro ou fora dessas fronteiras ameaçadas e das diferenciações decorrentes.

espaços imaginários

espaços ideológicos

quais ideologias organizam a imaginação

a negociação de espaços e de regimes espaciais

a negociação imaginária e concreta de regimes espaciais

não existem espaços inocentes 
ideologia, gramática, esfera pública

se a ideologia é a gramática de ideias de um determinado grupo de interesses, de suas representações internas e relações de poder, existem representações internas não ideológicas? e onde poderiam existir esses espaços não ideológicos, se a representação interna sempre é parte de uma produção de espaço e se a minha representação interna, ou partes da minha imaginação, sempre são o produto ou a junção associativa de determinadas ideologias intransigentes e parcialmente inconscientes?

espaço público

qual espaço público é público, ou melhor e talvez mais precisamente, qual espaço público é o lugar de certo tipo de esfera pública. uma esfera pública que reconhece e cria seus encontros como expressão que diz respeito a algo essencialmente geral/comum e público. esfera pública.

será que o espaço público é, antes de tudo, um espaço afetivo de uma autorreflexão simultaneamente individual e social? conforme as oportunidades de participação em dada esfera pública. e talvez seja até mesmo o deslizar para um determinado ambiente social? se a esse deslizar for outorgado um enquadramento que the garante a possibilidade de uma expressão pública, uma sensação de pertencimento a um contexto mental compartilhado do qual decorrem certos acordos, práticas de negociação e de espaço, onde encontra-se o espaço público daqueles aos quais é negada a participação por diversos motivos? que são excluídos da comunidade dos participantes? onde estão seus espaços, seus espaços públicos e sobre quais fundamentos, experiências e acordos se organizam as suas imaginações?

"todos querem ser parte de um movimento bem sucedido" disse um ativista entrevistado após o fracasso inicial do movimento dos acampados em jerusalém, confrontado com o "sucesso" do mesmo movimento em tel aviv. posteriormente, 
a situação se transformou e o sucesso se instaurou em jerusalém. mas o que é sucesso no que diz respeito ao espaço e ao movimento político? é a capacidade de impactar, e impactar as massas, o poder de impor efetivamente uma determinada representação interna e fazer com que ela se alastre na consciência de muitos?

o que significa sucesso em relação a uma prática espacial e na negociação de desejos políticos? bem sucedida é a representação interna que se impõe da maneira mais ampla possível, que se inscreve em muitas representações. sucesso de representação.

quais são os sistemas de referência e perspectivas em situações nas quais são encenados conflitos políticos? quais são os mecanismos das negociações? qual é o lugar da negociação?

perspectiva, posição e abstração

qual a minha perspectiva sobre algo e qual o meu posicionamento nas situações? como funciona a gramática das minhas ideias e a leitura das situações que exige a fabricação do espaço e a disposição de informações, conforme a minha perspectiva (olhar) e posicionamento (lugar/comportamento)?

porque eu falo sobre o que representa a injustiça dos outros, que me indigna? porque eu não quero viver em uma sociedade assim? porque faço isso e mudo assim a minha perspectiva na esfera política, assumindo a posição de outros? a formulação, em voz alta, de meus medos privatizados em público é um ato que pode modificar o espaço político?

falar sobre as situações políticas, assim como sobre outras narrativas e rearranjos ideológicos é parte da transformação de determinado processo de produção de espaços, já que esse processo redefine as gramáticas consensuais da sistematização de determinadas informações e suposições? 
e se eu, ao apontar as desgraças, medos e injustiças que tocam à mim, não posso incluir aqueles que são atingidos de maneira mais clara e profunda, porque eu falo a partir da minha posição?

qual o meu posicionamento concretamente social e econômico, a partir do qual eu começo a definir um local, na esfera das negociações sociais? qual é o interesse das minhas alianças territoriais ou demarcações na esfera das minhas atividades? (quer dizer na esfera das artes ou ainda no campo da ciência.)

será que cada um precisa, a partir da sua perspectiva e de seu lugar, determinar o espaço, discutir sobre ele e construí-lo? (o que acontece com aqueles "sem" voz, com aqueles que não querem se articular, ou que não conseguem, ou que não pertencem, ou não são compreendidos? de que espaço estamos falando nesse caso?) onde está um lugar, que pode se transformar em espaço?

será que espaço é frequentemente materializado a partir de ponderações ideológicas? ponderações, que, em parte, são produzidas em minha consciência também por meio de abstrações bidimensionais, através de mapas ou gráficos ou relações morais.

o que é o espaço que eu consigo produzir em relação ao espaço que a mídia produz? o espaço midiático, o bidimensional, que reúne informação visual e acústica e espera de mim outras imaginações. quais são os gatilhos dessas informações? como ordenam as informações midiatizadas as minhas ideias? como essas informações ordenam ao mesmo tempo a minha noção acerca do meio, da sua gramática e abstração e como estrutura ideológica?

mas mesmo assim, as ponderações mentais territoriais sobre esferas sociais, que são disputadas em certos lugares, são algo que difere fundamentalmente de suposições, projetadas e negociadas consensualmente.

o que é espaço?

uma esfera dinâmica na qual abstrações particulares são traduzidas em certezas? 
presença / voz / espaço - imaginação

o espaço na sobreposição de vozes. vozes que mantém espaços, vozes que falam entre si, sobre si. as transposições, as sobreposições criam valorizações.

vozes de um outro tempo. vozes, que nesse momento falam o que já foi falado; que o geram etc.

quando eu toco um arquivo de uma voz gravada em uma sala, essa voz existe nesse momento, nesse espaço. porque as informações sonoras da gravação, através da caixa de som, com a correspondente instalação, lugar, etc. fazem essa voz aparecer nesse espaço concreto. e a voz e o espaço e a minha presença se misturam para formar algo como uma presença presentificada. quando eu reproduzo uma voz de uma pessoa já morta em um espaço, essa pessoa ressurge com a voz pelo momento da reprodução. está lá, no presente. quando vozes de diferentes tempos se encontram em uma sala no mesmo tempo e se confrontam em uma constelação, que historicamente e situacionalmente nunca poderia ter ocorrido, acontece algo equivalente a uma reconfiguração da história e de suas possibilidades com base nas vozes e dizeres encontrados, confrontados e descobertos. recortes históricos que no presente, no momento do acontecimento e da minha escuta, se encontram.

toda a voz transporta um corpo e ao mesmo tempo a sua perecibilidade, porque o sopro que permeia as palavras nesse espaço desse corpo, torna novamente audível o corpo por meio do som e assim o faz ressurgir. porque?

a fala, que está sobre o papel, é fala que foi gerada por um corpo. eu vejo o corpo que a gerou, somente quando eu posso ler na letra, no percurso da caneta, ou na tinta sobre o papel, o tempo e a energia desse escritor. qual é o corpo que uma escrita impressa tem?

minha imaginação completa a voz, que toca em um aparelho, soa de certa maneira, para formar um corpo. lê a gravação como documento de uma situação em um espaço e ao mesmo tempo como documento de uma técnica de gravação. 
a voz gravada se torna um documento do corpo que a gerou, do corpo biológico do criador de sua sonoridade, de sua idade, de suas emoções, de sua relação com o dito e talvez com o endereçado.

ao mesmo tempo, a voz ressurge nesse espaço através da caixa de som, porque ela se espalha novamente no espaço, no qual eu escuto a voz. porque, se eu ouço uma voz, eu ouço também o espaço, no qual ela ressoa. de forma que a voz gravada, quando ressoa, vira presença e desenvolve uma presença no presente, diferente da filmagem de um morto, porque a imagem continua sendo sempre também imagem de um outro espaço.

presença, espaço

como está presente o espaço? a presença do espaço é a presença do seu recipiente como parte do espaço assim como as informações que permitem constituí-lo. a presença daquele que por meio da comparação entre o passado pessoal e outro cultural percebe, estabelece, sintetiza e avalia certas coisas, e as encaixa e sintetiza com as informações a elas atribuídas em sua imaginação, construindo espaço. o produz. uma parte essencial dessa síntese é a força da imaginação do "criador do espaço", do receptor das informações. a sua imaginação organiza, avalia e cria o espaço de acordo com a sua representação interna. o momento exato do processo de assimilação é o presente, a sequência temporal na qual as informações são justapostas em um local. elaborar essas informações implica em alinhá-las com uma experiência já vivenciada, um saber armazenado, uma narrativa conhecida de ou sobre esse espaço. pré-requisitos que organizam e sistematizam o aproveitamento do presente. a partir desse processo surge o espaço futuro, o espaço na imaginação do observador com o qual está sendo alinhado por sua vez o presente que continua acontecendo e, novamente, engendrará um futuro seguinte, que se tornará passado no presente.

por meio da luz eu vejo as informações no espaço. isso significa que a luz faz com que as coisas apareçam, se tornem visíveis. como é a minha relação com o espaço, com a luz, com o céu, no qual eu vejo sol, lua e estrela? o que eu vejo, quando eu 
olho para o céu noturno? o que eu vejo e quais saberes se misturam com esse ver? eu vejo estrela, ou mais precisamente a luz sobre uma matéria, que na verdade já é passado quando chega a mim; a estrela, que no local de onde eu olho o céu, se torna visível, é passado. anos luz. será que eu ainda consigo representar para mim o tempo e a distância? representação interna.

e porque foram atribuídas à determinadas constelações de estrelas imagens de animais que na verdade não são reconhecíveis quando eu olho para essas estrelas. abstração e imaginação. de onde surgiram? determinados pontos luminosos no céu foram, após longas observações, definidos como pertencentes de um mesmo grupo, porque não modificam suas relações internas. como esses pontos luminosos em relação se tornaram e tornarão uma constelação? que processo incrível! uma constelação sintetiza determinado ponto luminoso em um sistema e utiliza uma imagem para a tradução desse sistema. essa imagem será reunida com uma outra representação de objeto: um animal, um deus. mas que processo de abstração incrível de pontos observados no céu, pertencentes a um mesmo grupo, e sua transposição em uma simbologia criada a partir da imagem de animais (zodíaco). quais representações internas possibilitaram essa transposição e essa abstração? e porque ela se afirma e recai sobre o meu saber?

território, perfuração, imaginação

palco e estado, como conexão entre uma práxis política e uma práxis no teatro. “[...] o muro é o emblema e o ícone da separação. a separação entre cidadãos e não cidadãos. entre gaza e o banco ocidental. cada uma dessas unidades territoriais tem suas próprias regras para controlar o território. o muro é o ícone de todo um sistema de demarcações. cada fronteira cria tensão. e não existe somente para demarcar, ele está a serviço da separação e do controle sobre como tensão e contato surgem. assim como a circunstância de que o muro não ficou pronto. o muro não será finalizado, o muro não foi finalizado. isso é uma parte da lógica da demarcação, que faz da separação uma dinâmica e libera possibilidades para se intervir. o muro é o elemento mais bárbaro e destrutivo dessa lógica. é um 
monstro. nós chamamos o muro de rabo do monstro, porque o monstro é o regime. o muro é o rabo do monstro. [...]"

isso é um trecho de uma conversa de 21 de maio de 2012 com o filósofo adi ophir em tel aviv a respeito da questão como ele via o muro de segurança em/ao redor de israel. o muro planejado para ter mais de 110 quilômetros de extensão começou a ser construído em 2002, em defesa dos atentados suicidas palestinos e não foi definido como fronteira. um outro sistema existia entre cisjordânia e israel, estimado em 759 quilômetros, essa construção teve início em 2003. palestinos nas zonas de restrição não possuem direitos.

em outra conversa adi ophir disse que quando as construções do muro em israel iniciaram em 2002 a conclusão da obra estava prevista para 2005. ele não acreditou na época que o muro seria concluído. agora é 2012 e o muro existe em partes, de $60 \%$ a 2/3 foi de fato efetivado, o muro existe com lacunas, partes omissas, e ele está convencido de que este muro de segurança se torna mais eficiente através de suas lacunas.

o pensamento me confundiu e em posterior reflexão outros esclarecimentos me ocorreram: os mapas nas escolas de israel não possuem limites territoriais exatos. os mapas mostram uma região no oriente médio, sem demarcações precisas. assim todos os estudantes das escolas pensam primeiramente que israel não tem fim, como conta julie khromchenko em uma entrevista em jerusalem. e somente depois eles aprendem na escola a história das regiões ocupadas.

isso significa talvez que, se fronteiras são esboçadas, mas não marcadas efetivamente, elas não são uma alteridade precisa em relação a qual seria possível orientar-se. com os quais as pessoas poderiam se relacionar. senão, apenas marcas implícitas que devem ser organizadas só na imaginação de cada indivíduo e assim, entre o desaparecer e o elaborar, serão criadas coletivamente na cabeça e consciência de cada cidadão. a ameaça dessa marca e a possibilidade de revogação dessa marca, ou seja, a ameaça ideológica dessa separação cria até mais profundamente essa fronteira, como classificação de um dentro e fora. como 
inclusão e exclusão de uma estrutura territorial e simultaneamente nacional, e sempre também ideológica.

o que isso tudo tem a ver com teatro?

teatro nasce na cabeça. na insinuação de negociações, que nas comunicações de uma coisa com outra, na consciência dos seres singulares em conjunto, se ajustam e individualmente compõem emoção, comparação e sentido .

não por último, é a ameaça de um determinado estado ou de uma situação que evidencia sua realidade e faz ela se manifestar mais ostensivamente. a perfuração da continuidade faz com que, antes de tudo, surja a urgência de completá-la, imbricando-me como criador desta, no cenário ideológico de uma insinuação. a “liberdade" para criar representações internas é, antes de mais nada, parte de um determinado enquadramento conceitual e injunção para torná-lo mais completo. o enquadramento conceitual de um inimigo, de uma ameaça, de um outro, de uma estética do outro, é o que em primeiro lugar faz esse outro existir. já que a composição de "alguma coisa" sempre surge através da comparação desta com "outra”, se pensamos em sistemas binários, em constelações dialéticas. a distinção de algo, a sua exposição acontece por meio de sua diferença perante um outro. essas são talvez as regras básicas de escolhas estéticas, distinções. regras básicas de distinções éticas, regras básicas de distinções políticas.

como surgem os espaços e como surgem as distinções?

na imaginação dos indivíduos.

como essa imaginação é construída ou afetada?

ou a imaginação é algo completamente individual?

mas, se a imaginação é, em partes, sempre lembrança

de alguma coisa já conhecida, experienciada, que já tenha existido antes?

como esses elementos de minha comparação juntaram-se para formar uma imagem - mais ou menos dotada de sentido - de um acontecimento político ou cultural?

o que está lá?

o que eu percebo? 
o que eu juntei, de que maneira?

o que eu supus?

quais são os mecanismos e campos de tensão, que marcam os territórios da diferenciação? O que os redefinem, delimitam e ao mesmo tempo determinam?

relações, possibilidades, leitura

espaço é uma estrutura relacional entre arranjos materiais e processos de construção do espaço, que ocorrem em um lugar. martina löw designa isto de processos constituintes do espaço, que produzem esse espaço; o espaço, que o receptor sintetiza. ou seja, os processos que acontecem em um espaço fazem parte de um espaço. e a informação sobre os significados dos elementos, dos cenários, das ameaças, ou das dissociações se inscrevem imediatamente na análise ou percepção dos processos e, assim modificam o espaço. porque, ele não é um objeto, ou nesse sentido nada que não seja alterável, mas um fenômeno que foi gerado por mim, o receptor, o produtor. por meu saber, minhas crenças e emoções, percepções e meu pensamento.

ou de outra maneira

qual é o valor das coisas? o valor ou o significado revela-se sempre só no relacionamento com alguma outra coisa, na relação dos materiais, da superfície, da informação, do status, da sonoridade, do desejo que desencadeia algo, etc. sempre existe um enquadramento, que delimita esse relacionamento e cria os parâmetros; que gera valorizações por meio da relação dos elementos entre si e desses com minha perspectiva. a perspectiva da/ observação, o grau de informação existente no observador, a classificação avaliadora, o estado psicológico do observador exatamente nesse momento.

isso significa que objeto e informação se informam sempre mutuamente um ao outro e são classificados no registro de emoções e de lembranças do observador. ele determina, se quer determinar, o valor e a importância das coisas ofertadas para ele, ao mesmo tempo em que está co-determinado por valores e saberes da "cultura” que o cerca.

ou ainda de outra maneira 
o exemplo de uma leitura de um espaço:

em uma ilha, nosso locador diz ao cumprimentar-nos que o marido da nossa vizinha está gravemente doente e internado no hospital. não se sabe se ele voltará com vida para casa. desde então, observo os acontecimentos na casa de outra maneira. depois de alguns dias de vazio a mulher do doente chega com um homem que me parece ser seu irmão, interpreto a sua postura corporal e tento decifrar nela o estado de doença de seu marido. no mesmo dia, teve uma reunião. os mais velhos da vila estavam em frente a casa discutindo, esperando, telefonando. a minha suposição é de que o homem morreu e que o corpo seria levado para a casa, para o velório. eu leio o espaço baseado na minha informação. nós vamos embora. mas todos o indícios dos acontecimentos nessa casa ocorrem com o saber de que havia um homem à beira da morte ali. isso guia a minha leitura ou minha organização de todos os tipos de processos ao redor dessa casa. guia a leitura do espaço e dos processos dentro desse recorte espacial. a informação sobre o doente muda a minha leitura das ocorrências, negociações, ritmos de movimentos e da estadia das pessoas nessa casa. a reunião era o conserto coletivo de um defeito em uma bomba d'água. ah, sim, completamente diferente. dias depois chega alguém de novo na casa, na entrada estão penduradas uma jaqueta preta e uma camisa branca para arejar ...etc.etc.

o que são processos de construção do espaço, qual parte da construção do espaço é consciente, qual é atual, qual é "real"? qual parte da construção do espaço é regido por determinadas informações, saberes, cenários? qual parte da construção do espaço é uma retomada de emoções ou experiências do meu passado, gravadas em mim como parte de uma estrutura cultural, social e política. quais processos se referem a saberes científicos sobre cultura e natureza, que são conhecidos ou familiares para mim e que são as coordenadas de minha construção - subjetivamente social - do espaço?

o que é imaginação?

existe liberdade na representação interna? 
Figura 1 - O "muro de proteção" israelense, Maio 2012, no caminho de Jerusalém à Ramallah

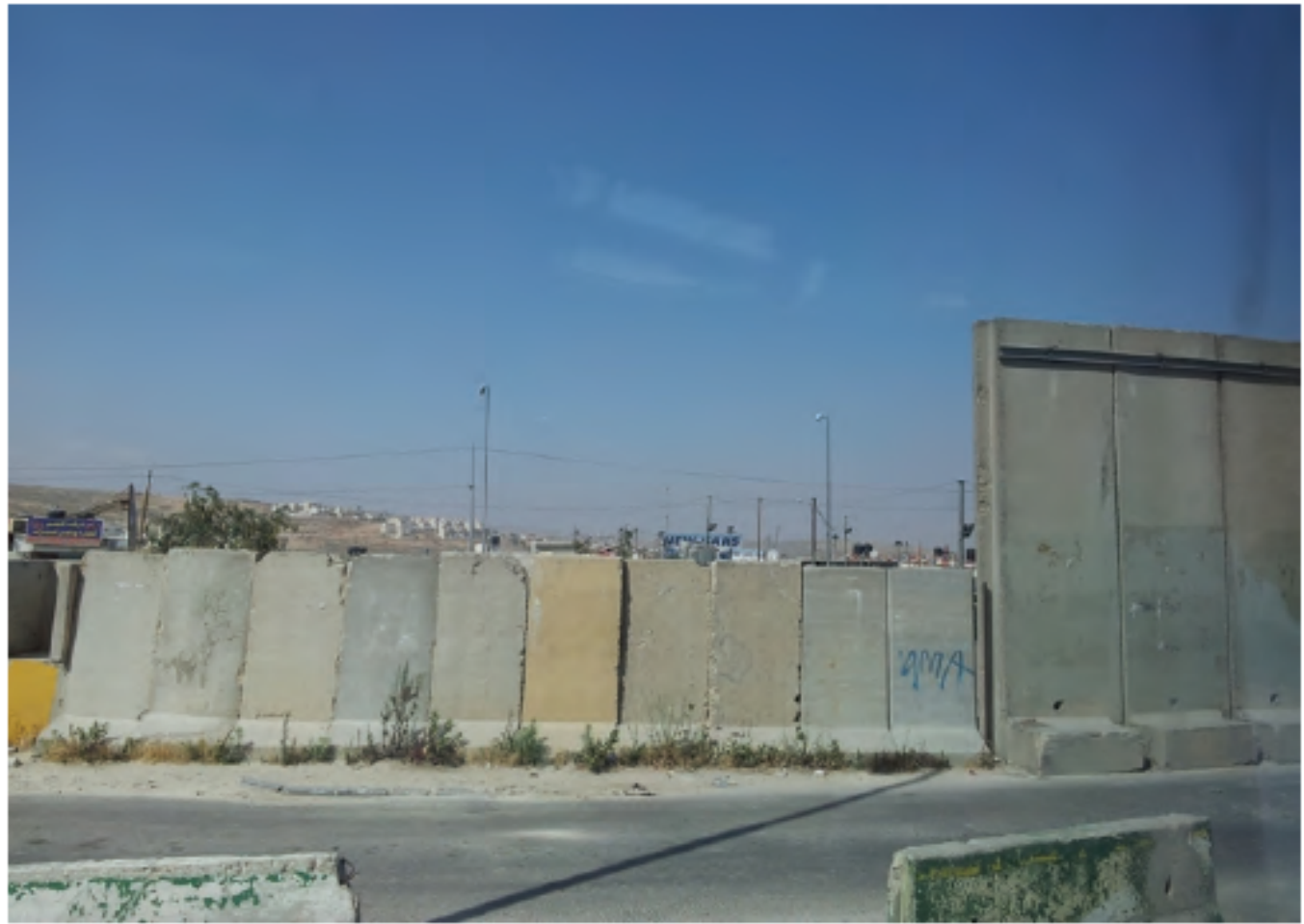

Figura 2 - Maio 2012, Tel Aviv

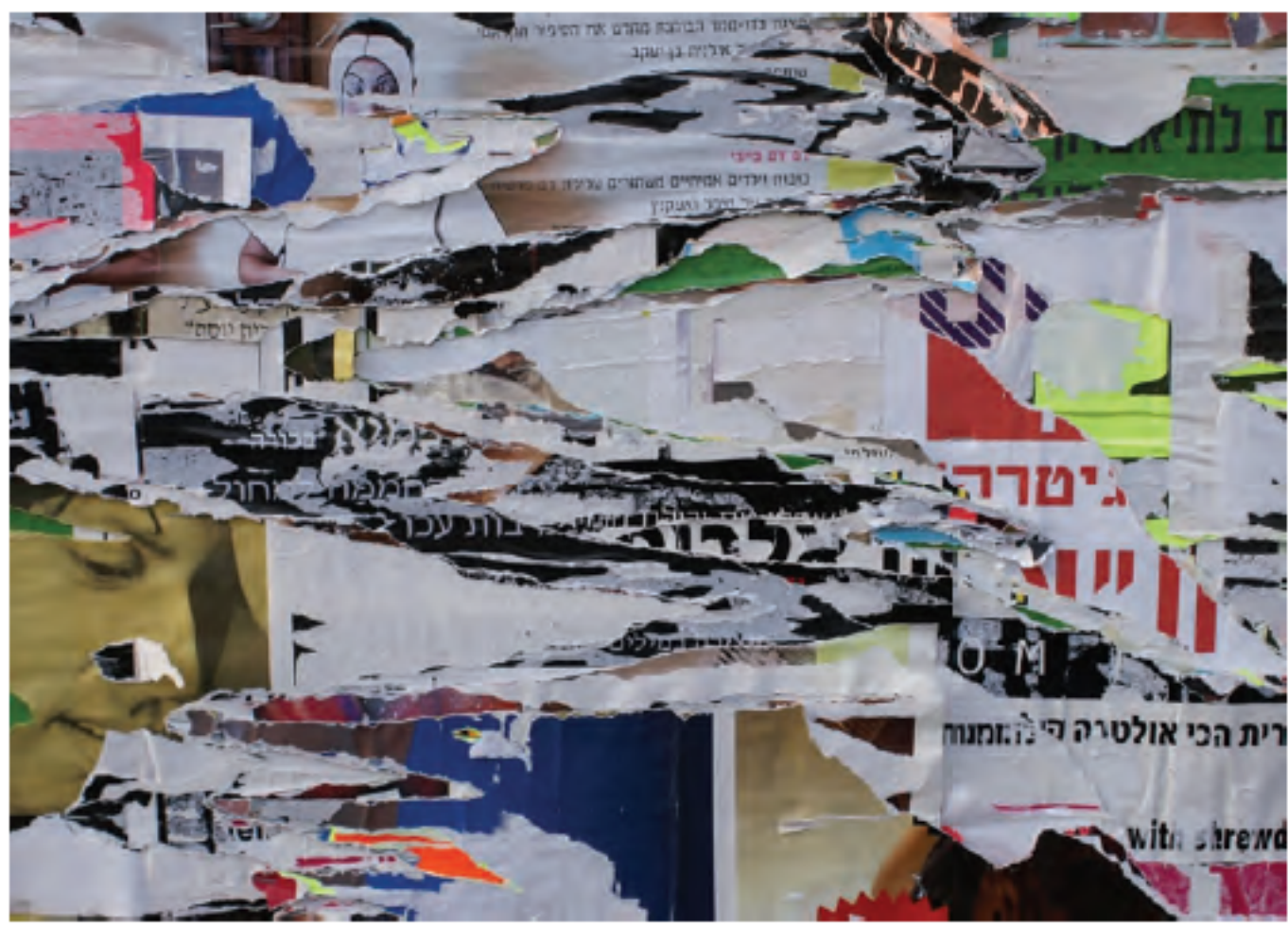


Figura 3 - Cena de rua, Junho 2012, Zurique (Suíça)

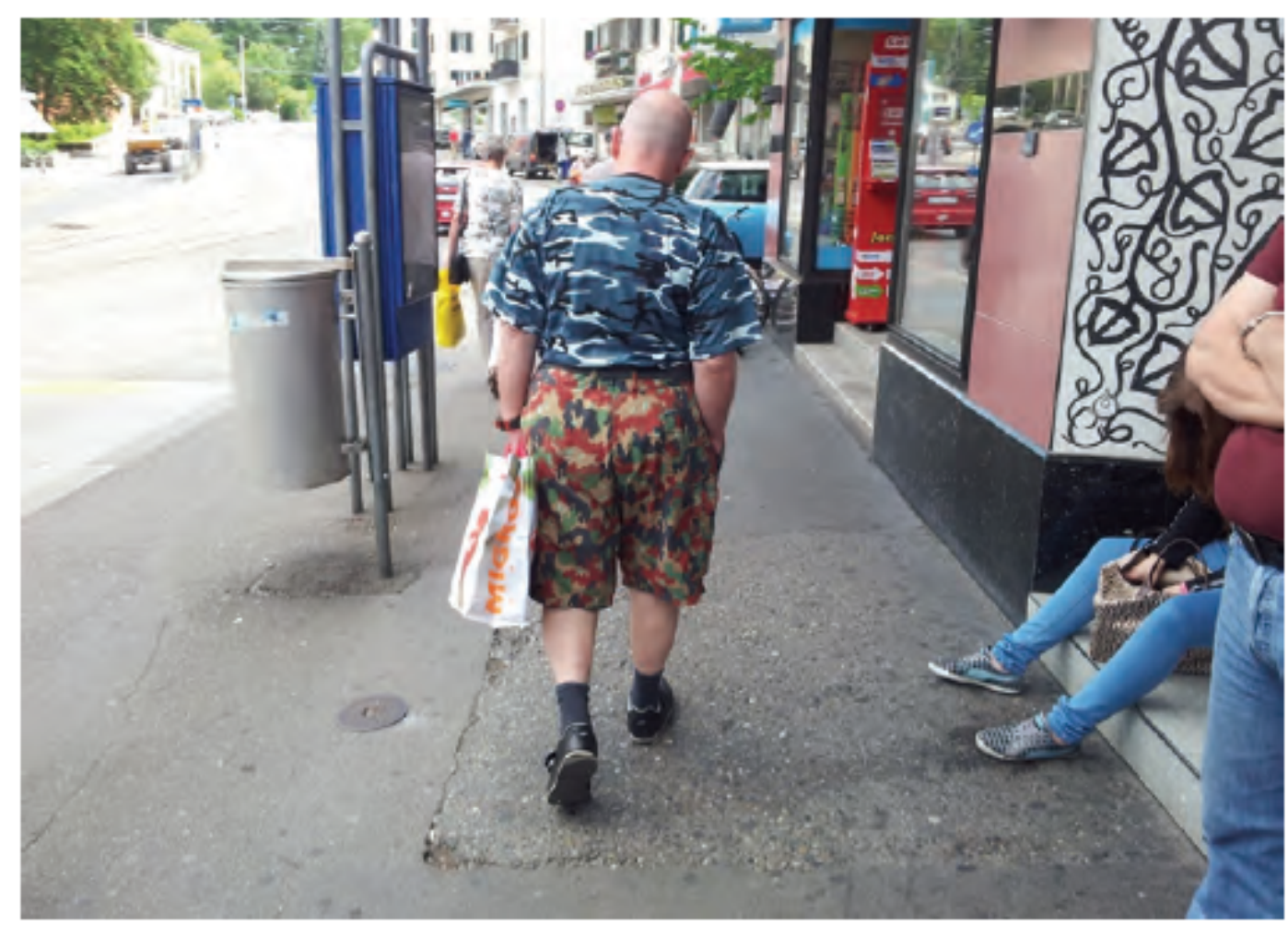

Figura 4 - A cama da minha avó, Abril 2012, Salzgitter (Alemanha)

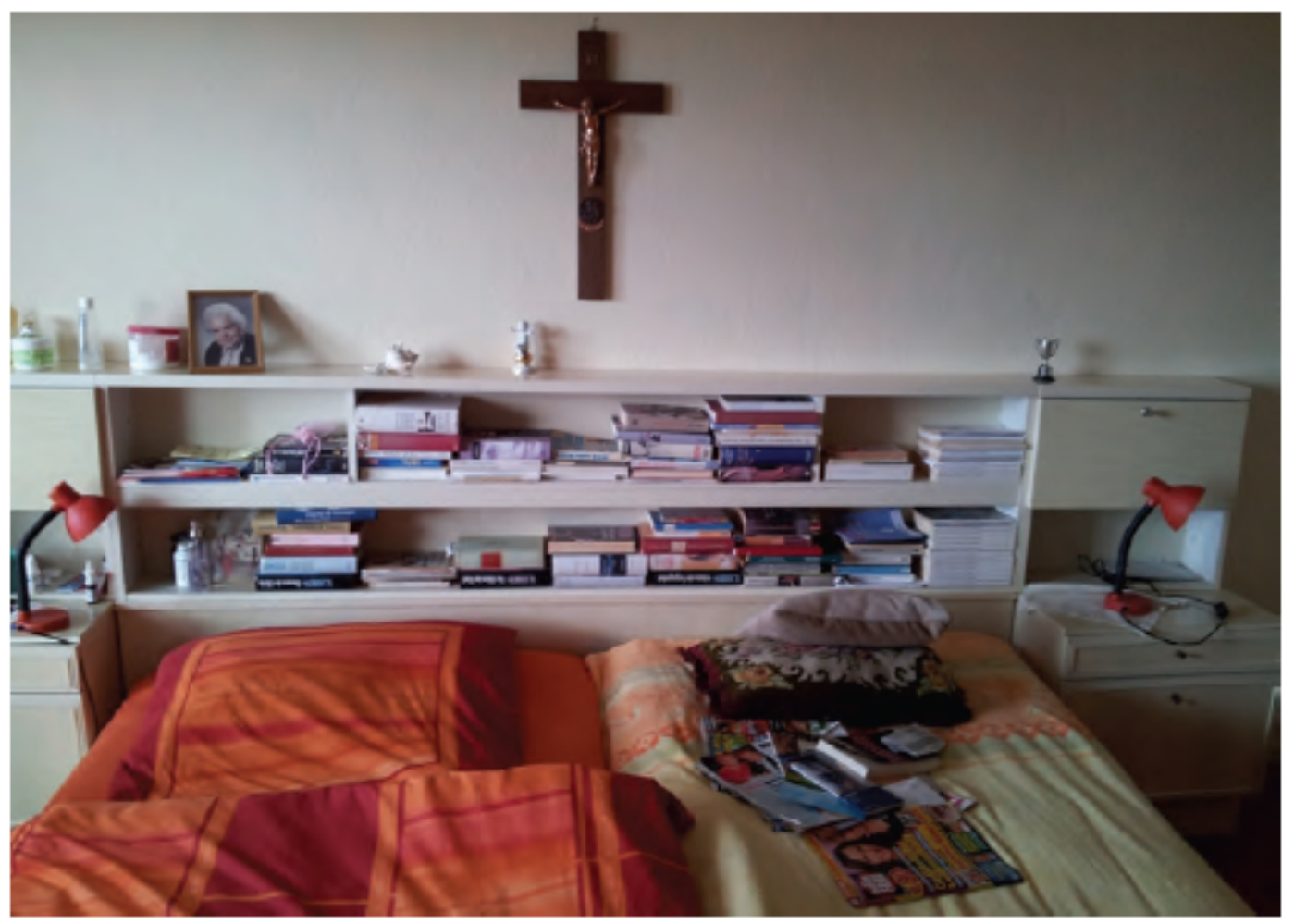




\section{Urdimento}

Figura 5 - Fragmento espacial de minha instalação "Biografical Landscapes of New Zagreb" Junho 2012 no Museu de Arte Contemporânea, Zagreb (Croácia)

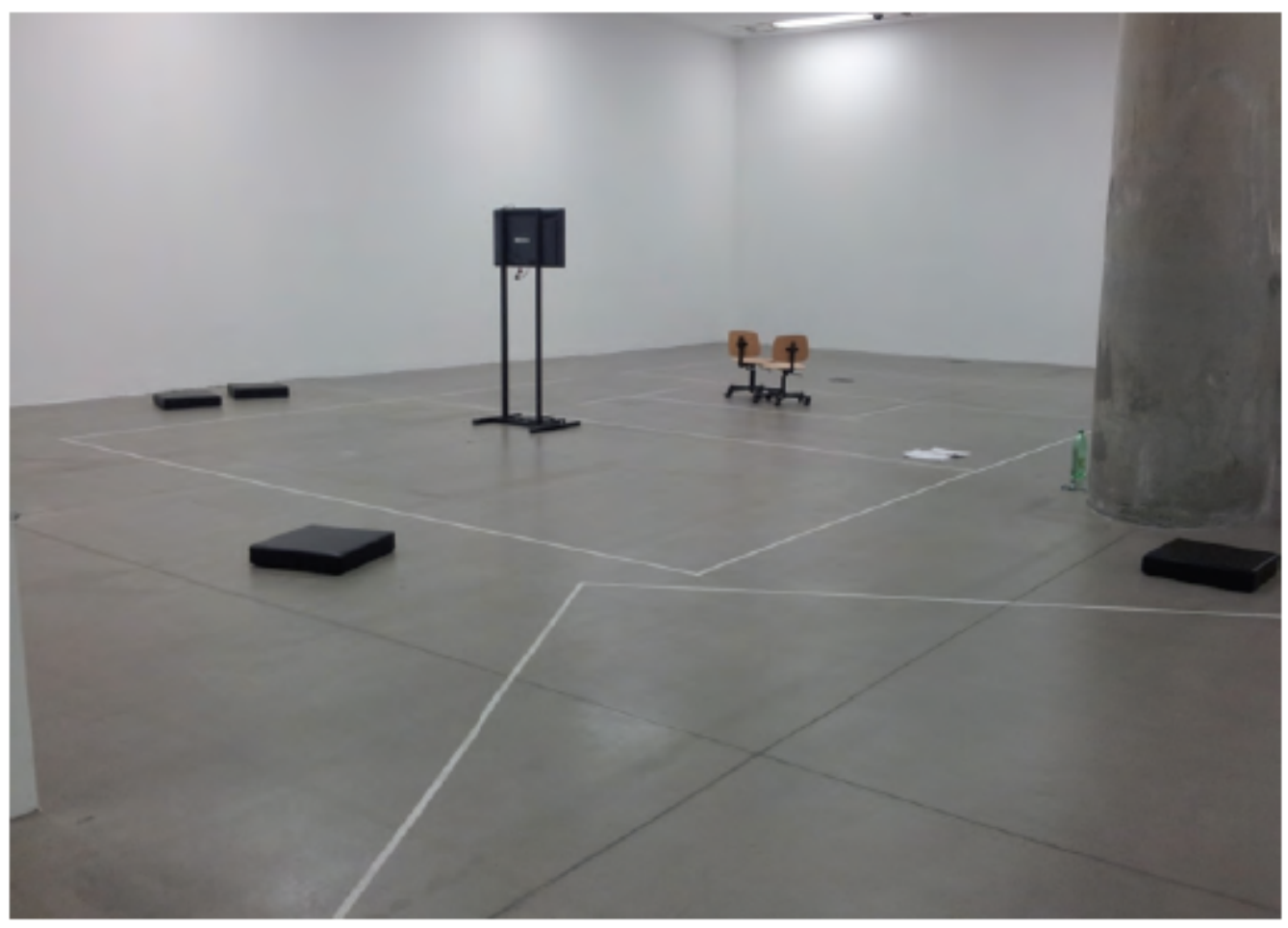

Figura 6 - Fragmento espacial de minha instalação "Biografical Landscapes of New Zagreb" Junho 2012 no Museu de Arte Contemporânea, Zagreb (Croácia)

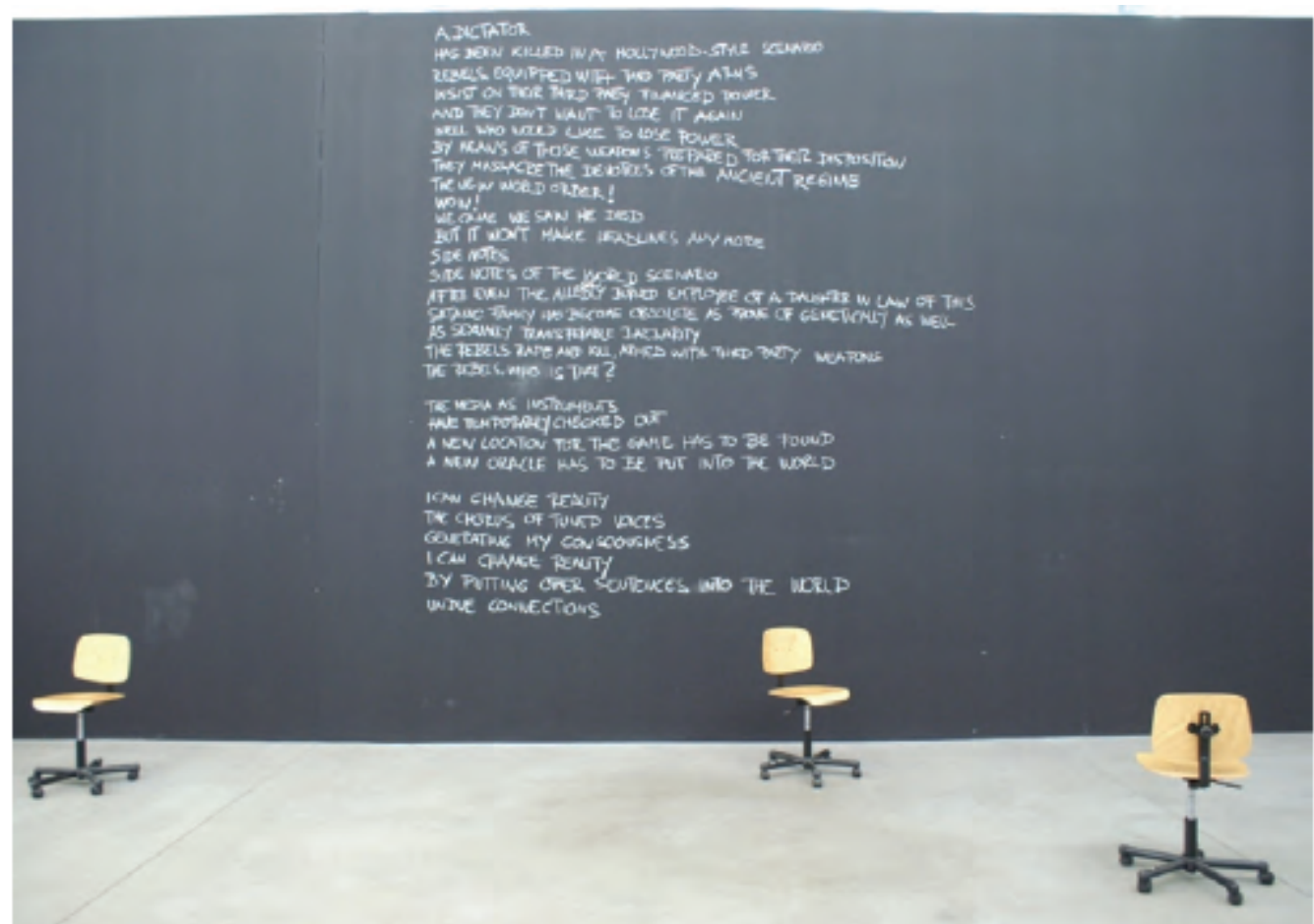




\section{Urdimento}

Figura 7 - Fragmento espacial de minha instalação "Biografical Landscapes of New Zagreb" Junho 2012 no Museu de Arte Contemporânea, Zagreb (Croácia)

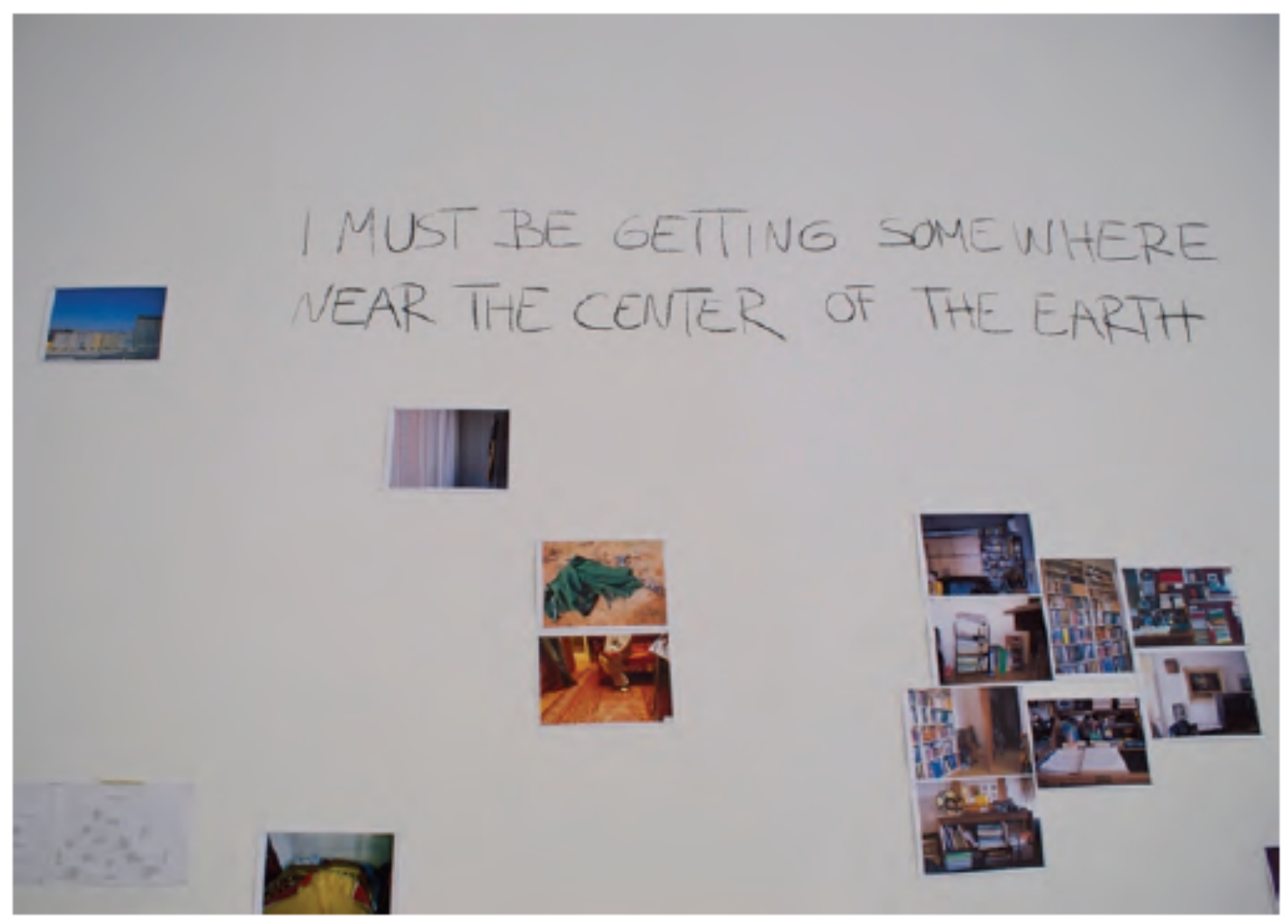

Recebido em: 3/07/2020

Aprovado em: 3/07/2020

\section{Universidade do Estado de Santa Catarina - UDESC \\ Programa de Pós-Graduação em Teatro - PPGT Centro de Arte - CEART Urdimento - Revista de Estudos em Artes Cênicas Urdimento.ceart@udesc.br}

